\title{
MOLECULAR ANALYSIS IN CHILEAN COMMERCIAL GASTROPODS BASED ON 16S rRNA, COI AND ITS1-5.8S rDNA-ITS2 SEQUENCES
}

\section{ANALISIS MOLECULAR EN GASTROPODOS CHILENOS COMERCIALES BASADOS EN LAS SECUENCIAS 16S rRNA,. COI Y ITS1-5.8S rDNA-ITS2}

\author{
Felipe Aguilera-Muñoz, Fabiola Lafarga-Cruz \& Cristian Gallardo-Escárate*
}

\author{
Laboratorio de Biotecnología Acuícola, Departamento de Oceanografía, Facultad de Ciencias Naturales y \\ Oceanográficas, Centro de Biotecnología, Universidad de Concepción. Barrio Universitario s/n. Casilla 160-C \\ Concepción, Chile. \\ email: crisgallardo@udec.cl
}

\begin{abstract}
Gastropod mollusks are part of the principal marine resources cultivated and commercialized in Chile. There are native Chilean species such as loco (Concholepas concholepas), locate (Thais chocolata), trumulco snail (Chorus giganteus), keyhole limpets (Fissurella spp.), tegula snail (Tegula atra) as well as exotic species such as red abalone (Haliotis rufescens) and Japanese abalone (Haliotis discus hannai). Despite their importance as marine resources, molecular genetic studies establishing phylogenetic relationships and estimating population genetic parameters are scarce. The aim of this study is to establish a molecular approach among the main commercial gastropod species in Chile. The mitochondrial genes 16S rRNA and COI, and the nuclear ribosomal region ITS1-5.8SrDNA-ITS2 were amplified by PCR and sequencing. Alignment analysis was used to determine systematic relationships at the specific level for the species studied. The results revealed that 7 species are grouped in 4 genetically distinct families (Haliotidae, Trochidae, Muricidae and Fissurellidae). In comparison with COI sequencing, 16S rRNA and ITS1-5.8SrDNA-ITS2 sequencing were relatively more conserved with a divergence percentage for 16S rDNA and ITS1-5.8SrDNA-ITS2 of $1.2 \%$ and $1.8 \%$, respectively, contrasting with the value of $10 \%$ obtained for COI in abalone.
\end{abstract}

KEYwORDS: 16S rRNA, COI, ITS1-5.8SrDNA-ITS2, gastropod mollusks, phylogenetic relationships.

\section{RESUMEN}

Los moluscos Gastrópodos son de los principales recursos marinos cultivados y comercializados en Chile. Hay especies nativas chilenas, como loco (Concholepas concholepas), locate (Thais chocolata), caracol trumulco (Chorus giganteus), lapas (Fissurella spp.) caracol tégula (Tegula atra), así como especies exóticas tales como abalón rojo (Haliotis rufescens) y abalón japonés (Haliotis discus hannai). A pesar de su importancia como recursos marinos, son escasos los estudios de genética molecular, relaciones filogenéticas y la estimación de los parámetros genéticos poblacionales. El objetivo de este estudio es establecer un enfoque molecular, entre las principales especies comerciales de gastrópodos en Chile. Los genes mitocondriales 16S rRNA y el COI, y la región nuclear ribosomal ITS1-5.8SrDNA-ITS2 fueron amplificados por PCR y secuenciación. Se utilizó el análisis de Alineación para determinar relaciones sistemáticas en el nivel específico de las especies estudiadas. Los resultados revelaron que 7 especies se agrupan en 4 familias genéticamente distintas (Haliotidae, Trochidae, Muricidae y Fissurellidae). En comparación con la secuenciación de COI, las secuencias de 16S rRNA e ITS15.8SrDNA- ITS2 fueron relativamente más conservada con un porcentaje de divergencia para 16S rDNA e ITS1-5.8SrDNAITS2 del 1,2\% y 1,8\%, respectivamente, en contraste con el valor del 10\% obtenidos para COI en abalón.

Palabras Clave: 16S rRNA, COI, ITS1-5.8SrDNA-ITS2, Moluscos gastrópodos, Relaciones filogenéticas. 


\section{INTRODUCTION}

Aquaculture in Chile is one of the principal productive activities, where the salmonids are the most important followed by bivalve and gastropod mollusks. The commercial importance of gastropod mollusks differs between native and exotic or introduced species. The principal native species are the "loco" (Concholepas concholepas), locate snail (Thais chocolata), trumulco snail (Chorus giganteus), keyhole limpets (Fissurella crassa) and tegula snail (Tegula atra), which are mainly obtained by natural extraction in volumes of 66 - 3902 tons (SERNAPESCA 2006). For the exotic gastropods, the abalones (Haliotis rufescens and Haliotis discus hannai) are the most important group in productive and industrial terms. According to Flores-Aguilar et al. (2007), abalone production in Chile in 2006 was 304 tons with a total value of US\$ 6,480 millions.

Despite their importance as marine resources, there are few molecular genetic studies establishing phylogenetic relations between taxa or connectivity interaction between natural populations for the Chilean coasts. Existing studies have focused on analyzing allozymes (Guiñez et al. 1992, Gallardo \& Carrasco 1996, Véliz et al. 2001, Gajardo et al. 2002), PCR-RAPD (Marín et al. 2007); PCR-RFLP (Olivares-Paz et al. 2006) and isolation of microsatellite loci (Cárdenas et al. 2007, Daguin et al. 2007). To date, there are no specific sequence analyses of the distinct taxa.

mtDNA sequences are highly valuable due to the large content of information clarifying high taxonomic limits (e.g.: Families) since mitochondrial genes evolve 10 fold faster than nuclear DNA. In contrast, nuclear genes exhibit few variations in the positions of their nucleotides at low taxonomic levels (Brown et al. 1979, Canapa et al. 2000, An et al. 2005). The mitochondrial gene 16S rDNA has been widely used in phylogenetic relationships studies in gastropods since it presents a high level of inter-specific polymorphism, and thus can be considered a mutational hot-spot (Thollesson 1999a, Thollesson 1999b, Holznagel \& Lydeard 2000, An et al. 2005). Additionally, the gene that codifies the protein cytochrome $c$ oxidase subunit I (COI) possesses a greater range of phylogenetic signal reflected in more parsimonious sites than other mitochondrial genes, and is also considered a robust evolutionary marker for determining inter-specific relationships (Hebert et al. 2003, Hershler et al.
2003, Remigio \& Hebert 2003, Grande et al. 2004, An et al. 2005). The upper ribosomal region (cluster 18S-ITS1-5.8S-ITS2-28S) is relatively conserved in its evolution, probably due to that ITS2 provides some of the signals that guide processing within the ribosomal nuclear region. Additionally, the capacity to predict secondary structure ITS2 has increased the value of the ITS region in phylogenic studies of mollusks (Coleman \& Vacquier 2002, Oliverio et al. 2002, Coleman 2003, Wood et al. 2007).

The aim of the present study is to establish the phylogenetic relationships of 6 commercially important gastropod mollusk species in Chile using partial sequences of mitochondrial genes $16 \mathrm{~S}$ rRNA and COI as well as the ribosomal region ITS15.8SrDNA-ITS2.

\section{MATERIALS AND METHODS}

SAMPLING. Table I indicates the sampling location of the species analyzed and the access number of the sequences deposited in GenBank. The samples were collected between August and September 2007.

DNAEXTRACTION, Amplification ANd SEQUENCING. Total genomic DNA was extracted from muscular tissue (foot) using an E.Z.N.A Tissue DNA kit (Omega Bio-Tek, USA) following manufacturer's instructions. The extracted DNA was visualized by an electrophoresis of agarose gel $1 \%$. The purification of high molecular weight DNA was compared with a $1 \mathrm{~Kb}$ molecular weight marker (New England BioLabs ${ }^{\varpi}$ ). Subsequently, the gel was observed using a digital photodocumentation system Ultracam $^{\circledast}$ (Model 4883) under ultraviolet light. The quantity and purity of the extracted DNA was measured using a ND1000 spectrophotometer $\left(\right.$ NanoDrop Technologies $\left.{ }^{\circledast}\right)$. The partial region of the genes 16S rRNA, COI and the ribosomal region ITS15.8S rDNA-ITS2 were amplified by PCR. The primers used for amplification of the 16S rDNA gene were 16Sar-L (5'-CGCCTGTTTAACAAAAACAT-3) and 16Sbr-H (5'-CCGGTTTGAACTCAGATCACGT-3') (Palumbi 1996). The primers used for the amplification of the gene COI were LCO1490 (5'GGTCAACAAATCATAAAGATATTGG- $3^{\prime}$ ) and HCO2198 (5'- TAAACTTCAGGGTGACCAAAAAATCA-3') (Folmer et al. 1994). In the case of abalones, they were F1 (5'TGATCCGGCTTAGTCGGAACTGC-3') and R1 (5'- GATGTGTTGAAATTACGGTCGGT-3') 
(Metz et al. 1998). The primers used for the amplification of the ribosomal region ITS15.8SrDNA-ITS2 were G-FOR (5'GGGATCCGTTTCCGTAGGTGAACCTGC-3') andGREV (5'-GGGATCCATATGCTTAAGTTCAGCGGGT3) (Coleman \& Vacquier 2002). The PCR reactions were performed in a final volume of $12.5 \mu \mathrm{L}$. Each reaction contains a buffer of PCR $1 \mathrm{X}$ (Invitrogen ${ }^{\mathrm{TM}}$ ), $0.2 \mu \mathrm{g} / \mu \mathrm{L}$ de BSA, $200 \mu \mathrm{M}$ dNTP's, $1.5 \mathrm{mM}$ of $\mathrm{MgCl}_{2}, 0.5 \mu \mathrm{M}$ of each primers, $0.1 \mathrm{U} / \mu \mathrm{L}$ de Platinum ${ }^{\circledast}$ Taq DNA Polymerase (Invitrogen ${ }^{\mathrm{TM}}$ ), miliQ water and $13 \mathrm{ng} / \mathrm{\mu L}$ of genomic DNA. The PCR reactions were performed in a Veriti ${ }^{\mathrm{TM}}$ (Applied Biosystem ${ }^{\circledR}$ ). The PCR conditions for the 16S rRNA gene were a initial denaturalization to $94^{\circ} \mathrm{C}$ for $2 \mathrm{~min} 30 \mathrm{sec}$, followed by 35 cycles at $94^{\circ} \mathrm{C}$ for $40 \mathrm{sec}, 50^{\circ} \mathrm{C}$ for $1 \mathrm{~min}$ and $72^{\circ} \mathrm{C}$ for $1 \mathrm{~min} 30 \mathrm{sec}$, with a final extension at $72^{\circ} \mathrm{C}$ for $5 \mathrm{~min}$. The PCR conditions for the $\mathrm{COI}$ gene were initial denaturalization at $94^{\circ} \mathrm{C}$ for $2 \mathrm{~min} 30 \mathrm{sec}$, followed by 5 cycles at $94^{\circ} \mathrm{C}$ for $30 \mathrm{sec}, 45^{\circ} \mathrm{C}$ for $40 \mathrm{sec}, 72^{\circ} \mathrm{C}$ for $1 \mathrm{~min}$, followed by 35 cycles at $94^{\circ} \mathrm{C}$ for $30 \mathrm{sec}, 52^{\circ} \mathrm{C}$ for $40 \mathrm{sec}$ and $72^{\circ} \mathrm{C}$ for $1 \mathrm{~min}$, with a final extension at $72^{\circ} \mathrm{C}$ for $5 \mathrm{~min}$. For abalone species, a PCR program was used with an initial denaturalization at $94^{\circ} \mathrm{C}$ for $2 \mathrm{~min} 30 \mathrm{sec}$, followed by 35 cycles at $94^{\circ} \mathrm{C}$ for $30 \mathrm{sec}, 53^{\circ} \mathrm{C}$ for $30 \mathrm{sec}$ and $72^{\circ} \mathrm{C}$ for $1 \mathrm{~min}$ with a final extension at $72^{\circ} \mathrm{C}$ for $5 \mathrm{~min}$. The PCR conditions for the ribosomal region ITS15.8SrDNA-ITS2 were an initial denaturalization at $94^{\circ} \mathrm{C}$ for $2 \mathrm{~min} 30 \mathrm{sec}$, followed by 35 cycles at $94^{\circ} \mathrm{C}$ for 40 sec, $56^{\circ} \mathrm{C}$ for $40 \mathrm{sec}$ and $72^{\circ} \mathrm{C}$ for $1 \mathrm{~min}$, with a final extension at $72^{\circ} \mathrm{C}$ for $5 \mathrm{~min}$.
The amplified products were visualized in agarose gel $1 \%$ stained with bromure etidium and compared with a $100 \mathrm{bp}$ molecular weight marker (New England BioLabs $\left.{ }^{\circledast}\right)$. The $\mathrm{PCR}$ products were purified and sequenced bidirectionally in an automatic $\mathrm{ABI}$ 3700 sequencer (Applied Biosystems ${ }^{\circledR}$ ) from Macrogen Inc. (Korea). The partial sequences of $16 \mathrm{~S}$ rRNA, COI and the ribosomal region ITS15.8SrDNA-ITS2 were sequenced for 5 individuals for each studied species.

Sequence analysis. The sequences were aligned using CLUSTALW (Higgins et al. 1994) and recorded in GenBank (Table I). The 16S RDNA, COI and ITS1-5.8SRDNA-ITS2 gene sequences were aligned with a total of $563 \mathrm{bp}, 521 \mathrm{bp}$ and $763 \mathrm{bp}$, respectively. The genetic distance was determined by the K2P parameter (Kimura 1980) using the software MEGA4 (Molecular Evolutionary Genetics Analysis) (Tamura et al. 2007).

The phylogenetic trees were constructed using the neighbor-joining method (Saitou \& Nei 1987) in MEGA4. The data were bootstrapped 1000 times to estimate the internal stability of each node. For the phylogenetic analysis, only one sequence was included per species (consensus sequence). Additionally, for the analysis of the genetic distances and phylogenetic relationships, sequences of representatives of the Haliotidae, Trochidae, Muricidae and Fissurellidae were obtained from GenBank.

TABLE I. Description of Samples used: Species, geographic origin, and GenBank access number for the molecular markers.

TABLA I. Descripción de muestras utilizadas: especies, origen geográfico, y acceso al número de GenBank para los marcadores moleculares.

\begin{tabular}{llllc}
\hline Species & Origin & COI & 16S rRNA & ITS1-5.8Sr DNA-ITS2 \\
\hline Haliotis rufescens & Coquimbo, Chile & EU636201 & EU636207 & EU636214 \\
Haliotis discus hannai & Coquimbo, Chile & EU636202 & EU636208 & EU636215 \\
$\begin{array}{l}\text { Concholepas concholepas } \\
\text { Thais chocolata }\end{array}$ & $\begin{array}{l}\text { Concepción, Chile } \\
\text { Antofagasta, Chile }\end{array}$ & EU636203 & EU636209 & \\
Fissurella crassa & Concepción, Chile & & EU636210 & \\
$\begin{array}{l}\text { Tegula atra } \\
\text { Choromytilus chorus }\end{array}$ & Concepción, Chile & EU636205 & EU636212 & EU636217 \\
\hline
\end{tabular}

${ }^{a}$ species used as outgroup 


\section{RESULTS}

Alignment of partial sequences of the 16S rRNA sequence (Figure 1) was $563 \mathrm{bp}$, including insertions and deletions. The divergence percentage of the commercial Chilean gastropod species was between $1.2 \%$ and $47.5 \%$. The genetic distance for the commercial gastropod species with the different families found in GenBank indicate that the species $H$. rufescens (AY428963) is closest to the individuals from the Trochidae family (T. atra EU636212), followed by the Muricidae ( $C$. concholepas EU636209 and T. chocolata EU636210) and Fissurellidae (F. crassa EU636211) families with values of $0.354,0.453,0.490,0.575$ respectively; for the species $H$. discus hannai
(AY146393), the genetic distances were 0.355, $0.453,0.490,0.570$ respectively (Table II). Figure 2 shows the phylogenetic relationships between the gastropod species and the sequences obtained from GenBank for the 16S rRNA gene. Four principal clusters corresponding to each family studied were found. For the Trochidae family, T. atra is grouped with $T$. funebralis, while two sub-clads can be observed in Muricidae, where one groups the genus Nucella and Ocinebrellus and the other consists in the genus Thais and the species $C$. concholepas. The species $T$. chocolata and C. concholepas are observed to be more related to $T$. savignyi and $T$. clavigera. In the Fissurellidae family, the Diodora is observed to be related with Fissurella crassa and Emarginula variegata.

TABLE II. Genetic distances inferred from the partial sequences of the 16S rRNA genes for the commercial gastropods and GenBank reports.

TABLA II. Distancias genéticas inferidas de secuencias parciales de los genes 16S rRNA para gastrópdos comerciales y reportes de GenBank.

\begin{tabular}{|c|c|c|c|c|c|c|}
\hline & H. $r$ & H. d h & C. $\mathrm{c}$ & T. ch & F. c & T. a \\
\hline \multicolumn{7}{|l|}{ Haliotidae } \\
\hline Haliotis rufescens AY428963 & 0.000 & 0.022 & 0.453 & 0.490 & 0.575 & 0.354 \\
\hline Haliotis corrugata AY428964 & 0.026 & 0.042 & 0.454 & 0.491 & 0.607 & 0.355 \\
\hline Haliotis cracherodii AY428965 & 0.019 & 0.042 & 0.452 & 0.489 & 0.583 & 0.366 \\
\hline Haliotis sorenseni AY428966 & 0.007 & 0.030 & 0.446 & 0.482 & 0.575 & 0.354 \\
\hline Haliotis fulgens AY428967 & 0.054 & 0.062 & 0.469 & 0.507 & 0.568 & 0.361 \\
\hline Haliotis kamtschatkana AY650163 & 0.007 & 0.030 & 0.446 & 0.482 & 0.575 & 0.354 \\
\hline Haliotis discus hannai AY146393 & 0.022 & 0.007 & 0.453 & 0.490 & 0.570 & 0.355 \\
\hline \multicolumn{7}{|l|}{ Muricidae } \\
\hline Thais clavigera $\mathrm{AB} 044249$ & 0.453 & 0.461 & 0.107 & 0.102 & 0.582 & 0.417 \\
\hline Thais savignyi AB044248 & 0.464 & 0.450 & 0.164 & 0.159 & 0.575 & 0.435 \\
\hline Ocinebrellus inornatus AY148713 & 0.440 & 0.463 & 0.235 & 0.220 & 0.491 & 0.424 \\
\hline Nucella lapillus DQ501691 & 0.427 & 0.449 & 0.230 & 0.215 & 0.500 & 0.406 \\
\hline \multicolumn{7}{|l|}{ Trochidae } \\
\hline \multicolumn{7}{|l|}{ Tegula funebralis AY163412 } \\
\hline & 0.344 & 0.352 & 0.409 & 0.429 & 0.439 & 0.094 \\
\hline Oxystele tabularis DQ061081 & 0.265 & 0.276 & 0.399 & 0.397 & 0.467 & 0.349 \\
\hline \multicolumn{7}{|l|}{ Fissurellidae } \\
\hline Emarginula variegata $\mathrm{AB} 238456$ & 0.476 & 0.454 & 0.591 & 0.592 & 0.360 & 0.466 \\
\hline Diodora cayensis AY377623 & 0.592 & 0.566 & 0.457 & 0.485 & 0.279 & 0.445 \\
\hline Diodora graeca DQ093476 & 0.660 & 0.641 & 0.508 & 0.521 & 0.292 & 0.510 \\
\hline
\end{tabular}

H. $r=$ Haliotis rufescens; $H . d h=$ Haliotis discus hannai; $C . c=$ Concholepas concholepas; $T$. $c h$ $=$ Thais chocolata $;$ F. $c=$ Fissurella crassa $;$ T. $a=$ Tegula atra . 
Molecular analysis among Chilean gastropods based in molecular DNA markers: AGUILERA F. ET AL.

TABLE III. Genetic distances inferred from the partial sequences of the COI genes for the commercial gastropods and GenBank reports.

TABLA III. Distancias genéticas inferidas de secuencias parciales de los genes COI para gastrópdos comerciales y reportes de GenBank.

\begin{tabular}{lccccc}
\hline & H. r & H. d h & C. c & T. ch & T. a \\
\hline Haliotidae & & & & & \\
Haliotis rufescens DQ297549 & 0.008 & 0.105 & 0.341 & 0.345 & 0.279 \\
Haliotis corrugata AY817719 & 0.081 & 0.094 & 0.353 & 0.332 & 0.303 \\
Haliotis cracherodii DQ297506 & 0.096 & 0.095 & 0.327 & 0.319 & 0.297 \\
Haliotis sorenseni AY817712 & 0.024 & 0.105 & 0.341 & 0.332 & 0.279 \\
Haliotis fulgens AY679081 & 0.090 & 0.104 & 0.374 & 0.312 & 0.345 \\
Haliotis kamtschatkana AY923920 & 0.020 & 0.100 & 0.334 & 0.325 & 0.285 \\
Haliotis discus hannai AF060847 & 0.086 & 0.008 & 0.361 & 0.338 & 0.310 \\
& & & & & \\
Muricidae & & & & & \\
Thais haemastoma U86330 & 0.339 & 0.373 & 0.274 & 0.292 & 0.293 \\
Ocinebrellus inornatus AY148790 & 0.289 & 0.321 & 0.273 & 0.273 & 0.295 \\
Nucella lapillus AF242178 & 0.332 & 0.367 & 0.297 & 0.243 & 0.265 \\
& & & & & \\
Trochidae & & & & & \\
Tegula funebralis AF080660 & 0.279 & 0.298 & 0.302 & 0.311 & 0.137 \\
Tegula gallina AF080661 & 0.305 & 0.317 & 0.302 & 0.255 & 0.153 \\
Tegula atra AF080663 & 0.273 & 0.316 & 0.306 & 0.266 & 0.004 \\
Oxystele tabularis DQ061090 & 0.315 & 0.334 & 0.312 & 0.307 & 0.281 \\
\hline
\end{tabular}

H. $r=$ Haliotis rufescens; H. $d h=$ Haliotis discus hannai; $C . c=$ Concholepas concholepas; T. ch = Thais chocolata T. $a=$ Tegula atra .

TABLE IV. Genetic distances inferred from the partial sequences of the ribosomal region ITS21-5.8SrDNA-ITS2 for the commercial gastropods and the GenBank reports.

TABLA IV. Distancias genéticas inferidas de secuencias parciales de los genes ITS21-5.8SrDNA-ITS2 para gastrópdos comerciales y reportes de GenBank.

\begin{tabular}{lcccc}
\hline & H. r & H. d h & F. c & T. a \\
\hline Haliotidae & 0.002 & 0.020 & 0.485 & 0.294 \\
Haliotis rufescens AF296855 & 0.012 & 0.016 & 0.488 & 0.297 \\
Haliotis corrugata AF296856 & 0.010 & 0.020 & 0.493 & 0.288 \\
Haliotis cracherodii AF296857 & 0.002 & 0.020 & 0.485 & 0.294 \\
Haliotis sorenseni AF296850 & 0.022 & 0.020 & 0.485 & 0.278 \\
Haliotis fulgens AF296859 & 0.000 & 0.018 & 0.489 & 0.297 \\
Haliotis kamtschatkana AF296853 & 0.016 & 0.012 & 0.493 & 0.299 \\
Haliotis discus hannai AF296858 & & & & \\
Trochidae & 0.281 & 0.287 & 0.475 & 0.036 \\
Tegula viridula AY682095 & & & & \\
Fissurellidae & 0.532 & 0.537 & 0.187 & 0.434 \\
Megathura crenulata AF296849 & & & & \\
\hline
\end{tabular}

H. $r=$ Haliotis rufescens; H. $d h=$ Haliotis discus hannai; F. $c=$ Fissurella crassa;

T. $a=$ Tegula atra. 
The alignment of the COI gene partial sequences (Figure 3) was de $521 \mathrm{bp}$, including insertions and deletions. The divergence percentage of the commercial Chilean gastropods was between 10\% and $34.9 \%$. The genetic distance of the commercial gastropod species with the representatives of the different families found in GenBank indicate that the species $H$. rufescens (DQ297549) is closer to the individuals of the Trochidae family ( $T$. atra EU636205), followed by the Muricidae family ( $C$. concholepas EU636203 and T. chocolata
EU636204) with values of $0.279,0.323,0.345$ respectively; while the genetic distances for the species H. discus hannai (AF060847) are 0.310, $0.343,0.338$ respectively (Table III). Figure 4 shows the phylogenetic relationships obtained from the COI gene partial sequences. Three principal clusters consisting in Haliotidae, Trochidae and Muricidae can be observed. The species of the Tegula genus are grouped in a single cluster, while $C$. concholepas and $T$. chocolata are observed to be outside of the principal clade of the family Muricidae.

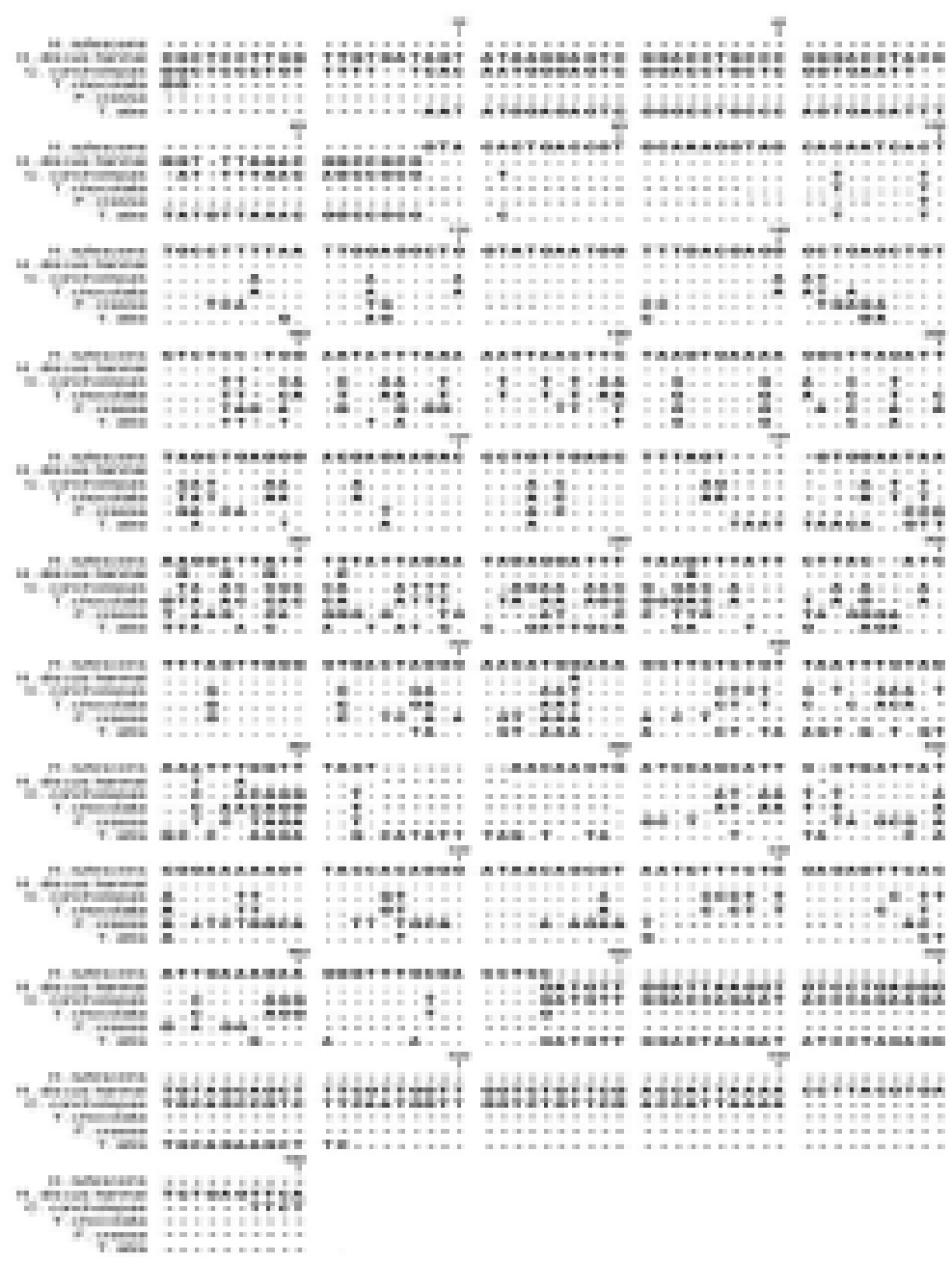

FIGURE 1. Partial sequence alignment for the 16S rRNA gene from 6 commercial gastropod species. (The gaps are indicated by a dash, identical nucleotides by a point).

FIgURA 1. Alineamiento de secuencia parcial para el gen 16S rRNA de 6 especies de gastrópodos comerciales (Los baches son indicados por un guión, los nucleótidos idénticos por un punto). 
Molecular analysis among Chilean gastropods based in molecular DNA markers: AGUILERA F. ET AL.

Partial sequence alignment of the nuclear region ITS1-5.8S rDNA-ITS2 (Figure 5) was 763 bp, including insertions and deletions. The divergence percentage of the species was between $1.8 \%$ and 43.7\%. The genetic distance indicates that the species H. rufescens (AF296855) is closer to the individuals of the Trochidae family ( $T$. atra EU636217), followed by the Fissurellidae family (F. crassa EU636216) with values of 0.294 and
0.485 respectively, while the genetic distances for the species H. discus hannai (AF286858) are 0.299 and 0.493 respectively (Table IV). Figure 6 shows the phylogenetic relationships obtained from the sequences of the ribosomal region ITS1-5.8SrDNAITS2. F. crassa together with Megathura crenulata within the Fissurellidae family and T. atra together with $T$. viridula within the Trochidae family can be distinguished.

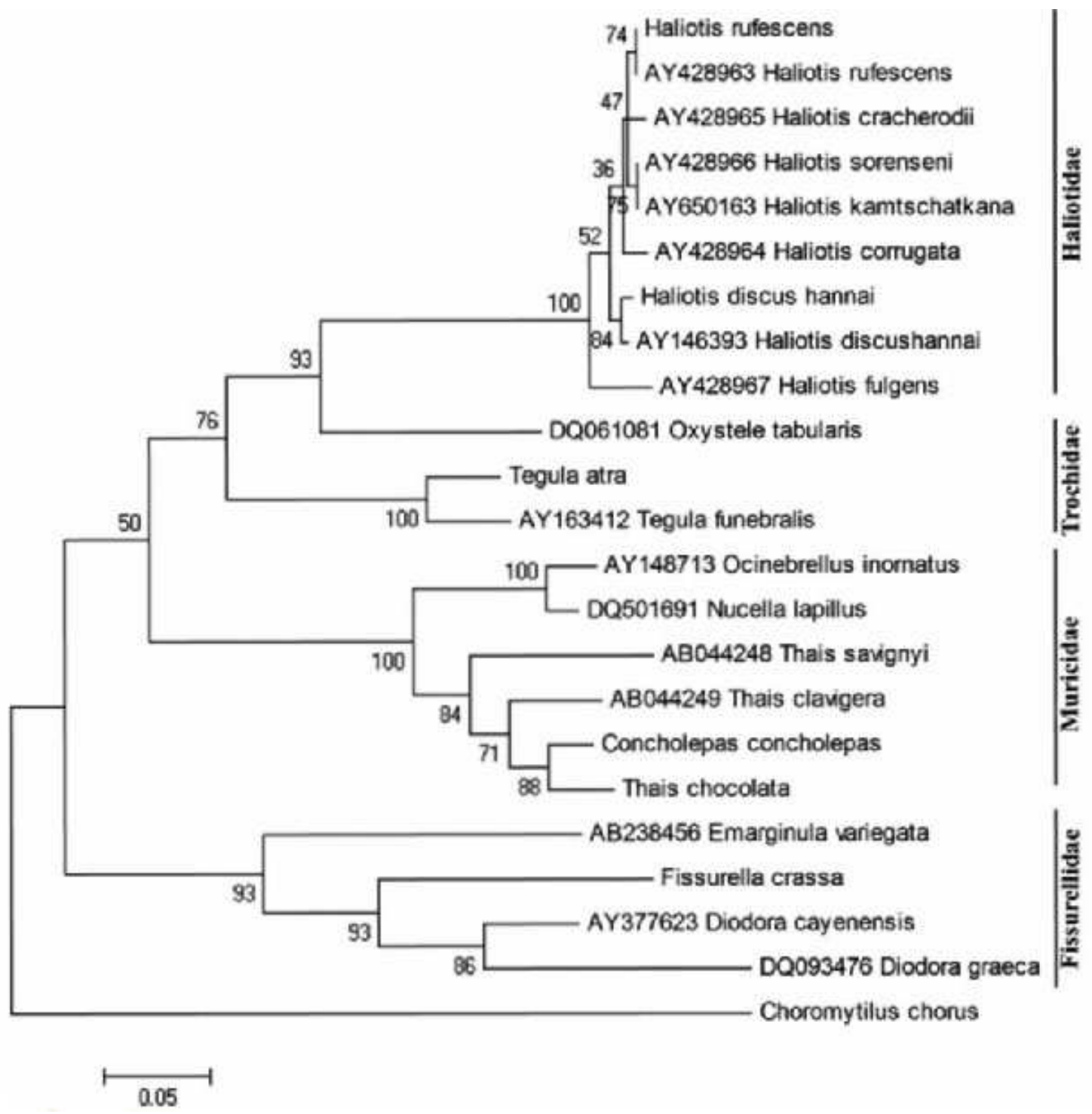

FIGURE 2. Tree indicating the phylogenetic relationships inferred from partial 16S rRNA gene sequences between the 6 commercial gastropod species and other representatives of families reported in GenBank.

FIGURA 2. Arbol indicando las relaciones filogenéticos inferidas de parciales secuencias de genes 16S rRNA entre 6 especies de gastrópodos comerciales y otros representantes de familias reportadas en el GenBank. 


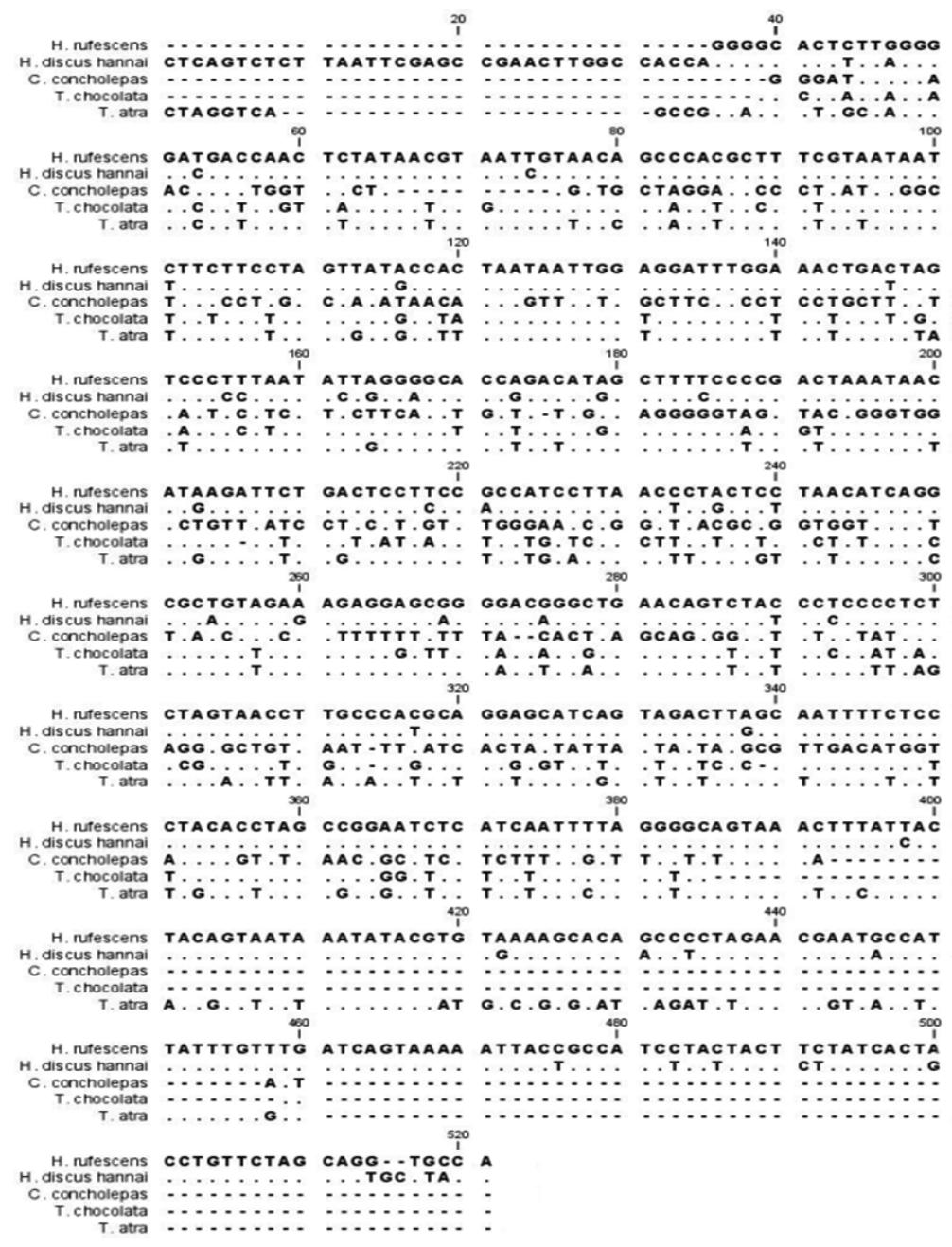

FIGURE 3. Partial sequence alignment for the COI gene of 5 commercial gastropod species. (The gaps are indicated by a dash, identical nucleotides by a point).

FiguRa 3. Parcial secuencia de alineamiento para el gen COI de 5 especies de gastrópodos comerciales (Los baches son indicados por un guión, los nucleótidos idénticos por un punto).

\section{DISCUSSION}

DNA molecular markers were used to assign the 6 commercial gastropod species present on the Chilean coasts to four phylogenetically related families as Haliotidae, Trochidae, Muricidae and Fissurellidae. For the Haliotidae family, this study demonstrated that Japanese abalone $H$. discus hannai is closely related to the California abalone species ( $H$. fulgens, $H$. corrugata and $H$. cracherodii), while $H$. rufescens is found to be evolutionarily close to the California species $H$. sorenseni and $H$. kamtschatkana. Several authors have reported this same result based on analysis of allozymes (Brown 1993), lysin cDNA sequences (Lee \& Vacquier 1995), mtCOI (Metz et al. 1998), mtCOII (Degnan et al. 2006), ITS1-5.8SrDNAITS2 (Coleman \& Vacquier 2002) and hemocyanine sequences (Streit et al. 2006). Additionally, the three DNA molecular markers used in this study demonstrate the phylogenetic closeness between Trochidae and Haliotidae with respect to Fissurellidae and Muricidae, respectively. Analysis of the gene sequences 16S rRNA and COI 
indicated a close relationship between the Chilean muricids $T$. chocolata and $C$. concholepas with respect to the Thais species reported in GenBank. It is likely that these results provide evidence of discordance in the classification of the species within the Thais genus. In this sense, observations on embryonic and larval development of the Thais genus show that the majority of the taxa share the same mode of embryonic development as well as the same size and number of eggs. Still, taxonomic aspects of larval development until the metamorphosis phase still need to be elucidated, and consequently some species will need to be reclassified. For example, the transfer of some Thais to the genus Nucella (Subfamily Ocenebrinae) has been based on differences in the larvalplanktotrophic development mode. According to paleobiological data described for Neogastrodopa, planktontrophic development modes can be proposed within the group as primitive characteristics in comparison with other, more recently evolved representative ones (Romero et al. 2004). The phylogenetic relationships found between T. clavigera, T. savignyi and T. haemastoma with respect to $T$. chocolata for the different mitochondrial markers could suggest that the Chilean species requires a new taxonomic review due to genetic distances and the nucleotide differences found. In this sense, other authors as Remigio and Hebert (2003) performed a phylogenetic analysis using COI sequences with different gastropod species, concluding that the Thais genus is evolutionarily close to the Nucella genus. The genetic distance values found in the present study indicate a close relationship between T. chocolata and Nucella lapillus (0.243) in comparison with $T$. chocolata and T. haemastoma (0.292). Additionally, Oliverio et al. (2002) analyzing ITS2 sequences in distinct gastropod species concluded that the genus Stramotina and Concholepas (Rapaninae) are found to be closely related to Nucella (Ocenebrinae).

Within the species of the Trochidae family, the Chilean species Tegula atra is located evolutionarily close to the species T. funebralis for $16 \mathrm{~S}$ rRNA, to the species T. gallina and T. funebralis for COI and to $T$. viridula for the ribosomal region ITS1-5.8S rDNA-ITS2. Hellberg (1998) analyzed the phylogenetic relationships of several species of the Tegula genus, finding that $T$. atra is closely related to the species $T$. funebralis and T. gallina, corroborating the genetic distance data obtained in the present study ( 0.137 and 0.153 , respectively). In the same study, the Chilean Tegula species are found to be located closer to Caribbean and Baja California ones.

Studies on the phylogenetic relationships in Fissurellidae species are scarce, and thus the present study presents the first approximations between these species. Analysis of the 16S rRNA gene indicated that the Chilean species Fissurella crassa is evolutionarily close to the Diodora genus from the Mexican and U.S. coasts. Due to the lower number of sequences reported for the ribosomal region ITS1-5.8S rDNA-ITS2, the phylogenetic relationships between the studied species and those reported in GenBank cannot be discussed.

\section{ACKNOWLEDGEMENTS}

This study was financed by FONDEF Grant D06I1027, D07/1085 and INNOVA 07CT9 PDT79. The authors thank Dr. Miguel Ángel del RíoPortilla for his suggestions and comments on the original version of the manuscript.

\section{REFERENCES}

An, H.-S., Y.-J. JeE, K.-S. Min, B.-L. Kim \& S.-J. HAN. 2005. Phylogenetic analysis of six species of pacific abalone (Haliotidae) based on DNA sequences of 16S rRNA and cytochrome $c$ oxidase subunit I mitochondrial genes. Marine Biotechnology 7: 373 - 380.

Brown, L. D. 1993. Biochemical genetics and species relationships within the genus Haliotis (Gastropoda: Haliotidae). Journal of Molluscan Studies 59: 429 - 443.

Brown, W. M., M. George \& A. G. WiLson. 1979. Rapid evolution of animal mitochondrial DNA. Proceedings of the National Academy of Sciences of the United States of America 76: 1967 - 1971.

Canapa, A., M. Barucca, A. Marinelli \& E. Olmo. 2000. Molecular data from the 16S rRNA gene for the phylogeny of Pectinidae (Mollusca: Bivalvia). Journal of Molecular Evolution 50: 93 - 97.

Cárdenas, L., C. Daguin, J. C. Castilla \& F. Viard. 2007. Isolation and characterization of 11 polymorphic microsatellite markers for the marine gastropod Concholepas concholepas (Brugière, 1789). Molecular Ecology Notes 7: 464 - 466.

Coleman, A. W. 2003. ITS2 is a double-edged tool for eukaryote evolutionary comparisons. Trends in Genetics 19: 370 - 375. 
Coleman, A. W. \& V. D. Vacquier. 2002. Exploring the phylogenetic utility of ITS sequences for animals: A test case for abalone (Haliotis). Journal of Molecular Evolution 54: 246 - 257.

Daguin, C., A. Brante, M. Fernandez \& F. Viard. 2007. Isolation of 10 microsatellite markers in Crepidula coquimbensis (Gastropod, Calyptraeideae) for parentage analyses. Molecular Ecology Notes 7: $1091-1093$.

Degnan, S. M., Imron, D. L. Geiger \& B. M. Degnan. 2006. Evolution in temperature and tropical seas: Disparate patterns in southern hemisphere abalone (Mollusca: Vetigastropoda: Haliotidae). Molecular Phylogenetics and Evolution 41: 249 - 256.

Flores-Aguilar, R., A. Gutiérrez, A. Ellwanger \& R. SearCy-Bernal. 2007. Development and current status of abalone aquaculture in Chile. Journal of Shellfish Research 26: 705 - 711.

Folmer, O., M. Black, W. Hoen, R. Lutz \& R. VRIJENHOEK. 1994. DNA primers for amplification of mitochondrial cytochrome $c$ oxidase subunit I from diverse metazoan invertebrates. Molecular Marine Biology and Biotechnology 3: 294 - 299.

Gajardo, G., J. M. Cancino \& J. M. Navarro. 2002. Genetic variation and population structure in the marine snail Chorus giganteus (Gastropoda: Muricidae), an overexploited endemic resource from Chile. Fisheries Research 55: 329 - 333.

Gallardo, M. H. \& J. I. Carrasco. 1996. Genetic cohesiveness among population of Concholepas concholepas (Gastropoda, Muricidae in Southern Chile. Journal of Experimental Marine Biology and Ecology 197: 237 - 249.

Grande, C., J. Templado, J. L. Cervera \& R. Zardoya. 2004. Phylogenetics relationship among Opisthobranchia (Mollusca: Gastropoda) based on mitochondrial $\operatorname{cox} 1$, trnV and $r r n L$ genes. Molecular Phylogenetics and Evolution 33: 378 - 388.

Guiñez, R., M. V. Gómez \& J. C. Castilla. 1992. Diferenciación genética poblacional en Concholepas concholepas (Brugiere, 1789) (Gastropoda, Muricidae) en su área de distribución centro-norte. Biología Pesquera 21: 31 - 41.

Hebert, P. D. N., S. Ratnasingham \& J. R. DeWaARd. 2003. Barcoding animal life: Cytochrome $c$ oxidase subunit 1 divergences among closely related species. Proceedings of the Royal Society of London B 270: S96 - S99.

HellberG, M. E. 1998. Sympatric sea shells along the Sea's shore: The geography of speciation in the marine gastropod Tegula. Evolution 52: 1311 - 1324.

Hershler, R., H.-P. Liu \& F. G. Thompson. 2003. Phylogenetics relationship of North American nymphophiline gastropods based on mitochondrial DNA sequences. Zoologica Scripta 32: 357 - 366.

HigGins, D., J. THOMPSON \& T. GiBSon. 1994. CLUSTAL W: improving the sensitivity of progressive multiple sequence alignment through sequence weighting, position-specific gap penalties and weight matrix choice. Nucleic Acids Research 22: 4673 - 4680.
Holznagel, W. E. \& C. Lydeard. 2000. A molecular phylogeny of Norht American Pleuroceridae (Gastropoda: Cerithioidea) based on mitochondrial 16S rDNA sequences. Journal of Molluscan Studies 66: 233 - 257.

Kimura, M. 1980. A simple method for estimating evolutionary rates of base substitutions through comparative studies of nucleotide sequences. Journal of Molecular Evolution 16: 111 - 120.

Lee, Y.-H. \& V. D. VAcquier. 1995. Evolution and systematics in Haliotidae (Mollusca: Gastropoda): inferences from DNA sequences of sperm lysin. Marine Biology 124: 267 - 278.

Marín, S. A., P. A. HAYE, S. Marchant \& F. M. Winkler. 2007. Molecular markers used analyze speciesspecific status in abalones with ambiguous morphology. Journal of Shellfish Research 26: 833 $-837$.

Metz, E. C., R. Robles-Sikisaka \& V. D. Vacquier. 1998. Nonsynonymous substitution in abalone sperm fertilization genes exceeds substitution in introns and mitochondrial DNA. Proceedings of the National Academy of Sciences of the United States of America 95: 10676 - 10681.

Olivares-Paz, A., J. Quinteiro \& M. Rey-Méndez. 2006. Autentificación de lapas del género Fissurella (Mollusca: Vetigastropoda) en la costa chilena, mediante PCR-RFLP. Investigaciones Marinas 34: 113 - 118.

Oliverio, M., M. Cervelli \& P. Mariottini. 2002. ITS2 rRNA evolution and its congruence with the phylogeny of muricid neogastropods (Caenogastropoda, Muricoidea). Molecular Phylogenetics and Evolution 25: 63 - 69.

Palumbi, S. R. 1996. Nucleic acid II: the polymerase chain reaction. In: M. G. Hillis DM, Mable BK (eds). Molecular systematics. (ed). Sinauer, USA. pp. $205-247$.

Remigio, E. A. \& P. D. N. Hebert. 2003. Testing of utility of partial COI sequences for phylogenetic estimates of gastropod relationships. Molecular Phylogenetics and Evolution 29: 641 - 647.

Romero, M. S., C. S. Gallardo \& G. Bellolio. 2004. Egg laying and embryonic-larval development in the snail Thais (Stramonita) chocolata (Duclos, 1832) with observations on its evolutionary relationships within the Muricidae. Marine Biology 145: 681 - 692.

SAITOU, N. \& M. NeI. 1987. The Neighbor-Joining method: A new method for reconstructing phylogenetic trees. Molecular Biology and Evolution 4: 406 - 425.

Sernapesca. 2006. Anuario Estadístico de Pesca. Servicio Nacional de Pesca, Available www.sernapesca.cl.

Streit, K., D. L. Geiger \& B. Lieb. 2006. Molecular phylogeny and the geographic origin of Haliotidae traced by haemocyanin sequences. Journal of Molluscan Studies 72: 105 - 110.

Tamura, K., J. Dudley, M. Nei \& S. Kumar. 2007. MEGA 4: Molecular Evolutionary Genetics Analysis (MEGA) Software version 4.0. Molecular Biology and Evolution 24: 1596 - 1599. 
Molecular analysis among Chilean gastropods based in molecular DNA markers: AGUILERA F. ET AL.

Thollesson, M. 1999A. Phylogenetic analysis of dorid nudibranchs (Gastropoda: Doridacea) using the mitochondrial 16s rRNA gene. Journal of Molluscan Studies 65: 335 - 353.

Thollesson, M. 1999в. Phylogenetic analysis of Euthyneura (Gastropoda) by means of the $16 \mathrm{~S}$ rRNA gene: use of a «fast» gene for «higher-level» phylogenies. Proceedings of the Royal Society of London B 266: 75 - 83.

Véliz, D., C. Guisado \& F. M. Winkler. 2001. Morphological, reproductive, and genetic variability among three populations of Crucibulum quiriquinae (Gastropoda: Calyptraeidae) in northern Chile. Marine Biology 139: 527 - 534.

Wood, A. R., S. Apte, E. S. MacAvoy \& J. P. A. Gardner. 2007. A molecular phylogeny of the marine mussel genus Perna (Bivalvia: Mytilidae) based on nuclear (ITS1\&2) and mitochondrial (COI) DNA sequences. Molecular Phylogenetics and Evolution 44: 685 - 698.

Recibido: 19.11 .08

Aceptado: 10.04.09 